the Service in 1920. He settled in Bristol and was appointed Hon. Consulting Surgeon to the Bristol Eye Dispensary, where he worked for many years, and did some consulting practicè. He retired on account of ill-health and went to live near Stroud.

As an old colleague and friend I would like to add a personal tribute to a man who served his profession so ably, and his friends so faithfully. He had a very keen mind, was a hard worker, read widely, and in other languages had kept himself up-to-date.

Lister was a doctor of the very best type, a true Christian gentleman, self effacing and unselfish, always ready to help in every good work. He was painstaking to a degree in treating his patients, and much loved by them both in India and in this country. He leaves a widow and a daughter.

\title{
BERNARD HAMILTON ST. CLAIR ROBERTS
}

Mr. Harrison Butler writes:-

I think that it was in 1911 that I first met Roberts, the beginning of a friendship that lasted till his death on December 19, 1943. This was when we were founding the Midland Ophthalmological Society. He was an original member and held the office of president in 1929 and 1930 . As secretary of the society I saw a great deal of him and learned to love his simple lovable nature, and to appreciate his devotion to his professión, and his determination never to miss an opportunity of gaining knowledge. He was rarely absent from the meetings of the Ophthalmological Society, the Oxford Congress, and the Midland Ophthalmological Society, and he will be greatly missed by his colleagues at future meetings. $\mathrm{He}$ did not often speak, but when he did he always showed a sound practical knowledge of ophthalmology. He had a retiring nature and did not publish much, but he made a study of ray-cataract which in the form of chain-maker's cataract used to be common at Cradley Heath, and so Roberts had a great experience at the Guest Hospital at Dudley of this form of cataract. His 'paper on this 'subject, published in this Journal, Voll. V, p. 210, 1921, was one of those which led to chain-maker's and puddler's cataract being scheduled under the Workmen's. Compensation Act. In 1.925 Roberts gave the Middlemore Lecture on "senile changes in the eye."

B. H. St. Clair Roberts was the son of a dental surgeon who practised in Dudley. He went to the Sebright School, Wolverley, and then studied medicine at the Birmingham University, qualify: ing in 1900. He became house surgeon to the Wolverhampton Eye Infirmary and then to the Birmingham Eye Hospital. He started prattice in Dudley and opened an eye department at the Dudley Dispensary. This was eventually removed to the Dudley Guest Hospital where Roberts became ophthalmic surgeon till 1940. In 1911 he was appointed surgeon to the Worcester City and County 


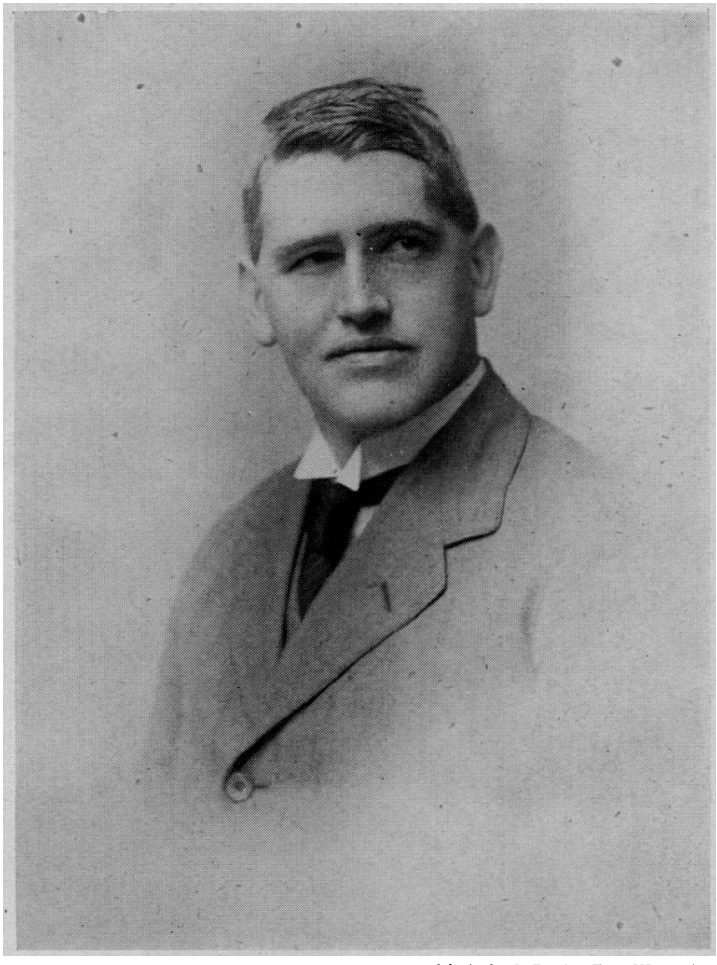

I'hoto by I. Parkes Foy, Worcester

B. H. ST. CLAIR ROBERTS

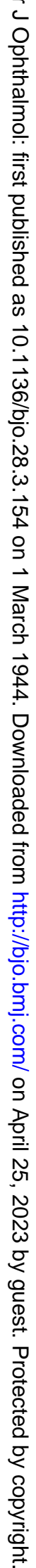


Eye Hospital, and he was still in active service at the hospital at the time of his death, in fact he attended his clinic there on the very day that he was taken ill, but a few days before the end. I once saw Roberts extract a cataract at this hospital. He suffered from infantile paralysis, and he had to rest his elbow on a cushion to make the section. I was amazed at the skill he showed, seeming not at all to be handicapped by his infirmity. In 1937 he started an orthoptic clinic and the work increased so rapidly that it soon was necessary to build a special building for the squint work. In 1940 he was at last able to instal a Mellinger ring magnet at the hospital, which had moved from the old building in Castle Street to the present hospital in Barbour Road.

I know from my own experience in the neighbouring district that Roberts had become a household name in Worcestershire. I have seen many of his patients and they all witness to his honest work, his gentleness, and his skill. He was universally loved by all the working classes, and he will be greatly missed, not only by his patients, but by the whole medical profession of the district. We have lost a dear friend, and a kindly, gentle soul. I have never heard anyone say an unkind or derogatory word about him.

'Much sympathy will be felt for his widow and her only son who. is a medical student at Oxford.

\section{E. FERREE}

WHEN Dr. Ferree died on July 26, 1943, only the bare fact was noted in this journal, and at the same time the hope was expressed that we should be able to give some details of his career in a later number.

Mrs. Ferree has kindly sent us a brochure made up of obituary notices reprinted from the Archives of Ophthalmology, the American Journal of Psychology, and from the Optical Society of America, together with miscellaneous notes on the development of his work made by himself in February, 1942, and a very complete and most useful bibliography of his published papers which amounts to 250 items.

To this brochure we are indebted for the facts which follow: Dr. Ferree was born in Sydney, Ohio, March 11, 1877. He took the B.A. and M.A. from the Ohio Wesleyan University and in 1902 became Sage fellow in psychology at Cornell University. In 1909 he was awarded the Ph.D. at Cornell and 30 years later his old University gave him the D.Sc. For more than 35 years he was at work on the sensory functions " and the evaluation of methods for their accurate control, recording and measurement." The work of "Ferree and Rand" is well known in Britain, seyeral of their papers having appeared at various times.in our pages. One of their last 